\title{
USING NATURAL ADDITIVES FOR INCREASING SHELF LIFE OF PIZZA
}

\author{
AYMAN E.M. SOLIMAN, HALA M.Z. ALI AND NADIA M. ABD EL-MOTALEB
}

Food Technology Research Institute, Agricultural Research Center, Giza, Egypt

(Manuscript received 1 August 2010)

\begin{abstract}
In later years, there is an increasing interest for new natural antimicrobial compounds due to negative effect of artificial food preservatives on human health therefore, in this study the dill, celery and parsley seeds were added individually at levels 1.5 and $2 \%$ before baking on surface pizza and its essential oils which were extracted from these seeds were added individually at levels 400 and $600 \mathrm{ppm}$ after baking on pizza surface. The results demonstrated that physicochemical properties of essential oils were in standard limit. Sensory evaluation of pizza showed that pizza color with three seeds additives and pizza taste with dill seeds essential oil added significantly differed taste compared with control sample. GC/MS apparatus estimated 15, 13 and 14 components present in dill, celery and parsley essential oils respectively. Antimicrobial activity of essential oils indicated that essential oils gave greater antimicrobial activity in gram positive bacteria than that in gram negative bacteria, also, essential oils had higher antimolds activity than that of bacteria and yeast. Total count of microorganisms in pizza revealed that adding three essential oils increased shelf life of pizza as compared with adding the three seeds.
\end{abstract}

\section{INTRODUCTION}

Natural antimicrobials, such as spices and spice extracts, for reducing and eliminating pathogen and spoilage microorganisms from fresh produce can be used as an alternative treatment. There is an increasing interest in the possible use of natural compounds to prevent microbial growth in the food items which will result in additive free, fresher and more natural tasting food products. Thus, Consumers all over the world are becoming increasingly conscious of the nutritional value and safety of their food and its ingredients. At the same time, there is an increase preference for natural food and food ingredients which are generally believed to be safer, more healthy and less subject to hazards than food containing artificial food additives (Karapinar et al., 2005).

Recently, there is a growing interest in substances exhibiting antimicrobial and antioxidant properties that are supplied to human and animal organisms as food components or as specific pharmaceutics. It has been well-known that essential oils have antimicrobial and antioxidant effects. Also, common need is available in natural extracts which give a pleasant taste and/or smell combined with a preservative action, 
aimed to avoid lipid deterioration, oxidation and spoilage by microorganisms (Sacchetti et al., 2005).

Since ancient times, herbs and spices have been added to different types of food to improve the flavor and organoleptic properties. Also, herbal medicines have a great potential in the emerging nutrition industry, because these materials are often considered foods as well as medicines and are used in preventive and curative treatments throughout the world. Especially popular today is the concept of foods that combine nutritional and medicinal benefits, so- called "functional foods" many natural compounds extracted from plants have demonstrated biological activities. Among these various kinds of natural substances, essential oils from aromatic and medicinal plants receive particular attention as potential natural agents for food preservation. In fact, their effectiveness against a wide range of microorganisms has been repeatedly demonstrated (Marino et al., 2001).

Essential oils obtained from plants by steam distillation, pressing or extraction, in addition to their characteristic aroma and flavor, usually contain phenolic compounds with a certain level of antimicrobial and antifungal activity. The activity of essential oils against microorganisms is strongly dependent on the food system in which they are used. It also depends on other variables, for example, plant variety, climatic factors and extraction method. These essential oils have been shown to have useful antimicrobial activity at concentrations suitable for use in food processing (Shelef et al., 1980).

Essential oils (EOs) (also called volatile or ethereal oils) are aromatic oily liquids obtained from plant material. About 300 essential oils are known commercially important-destined chiefly for the flavours and fragrances market. Among the herbs and spices and its oils best known for their antimicrobial properties are celery seeds, dill seeds and parsley seeds (Farrell, 1999).

The present study has been planned to evaluate the efficiency addition of dill, celery and parsley seeds and its essential oils on sensory evaluation and microorganisms content of pizza.

\section{MATERIALS AND METHODS}

\section{Materials:}

Dill seeds (Anethum graveolens L.), celery seeds (Apium graveolens L.) and parsley seeds (Petroselinum sativum M.) were obtained from Medicinal and Aromatic Plant Research Department, Agriculture Research Center, Giza, Egypt .

Wheat flour (72\% extraction) was obtained from Middle and West Delta Mills Company, Cairo, Egypt . 


\section{Microorganisms:}

Strains used were as follows: Four strains of gram positive bacteria, Bacillus cereus (ATCC14579), Bacillus subtilis (CGMCC 1.4681), Listeria monocytogenes (NRRL, 1951) and staphylococcus aureus (ATCC 25923). Two strains of gram negative bacteria, Escherichia coli (ATCC 25922), Pseudomonas aeruginosa (ATCC 278530). Four strains of molds, Aspergillus niger (ATCC 6880), Fuzarium oxysporum (CGMCC 3.12), penicillium citrnium (CGMCC 3.27) Rhizopus nigricans (CGMCC 3.37). One strain of yeast, candida albicans (ATCC 14053). All strains were obtained from Faculty of Pharmacy, Zagazig University, Egypt. The bacterial strains were grown in Mueller Hinton Agar (MHA) plates at $37^{\circ} \mathrm{C}$, while the fungi (molds and yeast) were grown in Sabouraud Dextrose Agar (SDA) and potato dextrose agar (PDA) media, respectively, at $20^{\circ} \mathrm{C}$.

\section{Methods:}

\section{Extraction of essential oils:}

The seeds of dill, celery and parsley were individually ground, then mixed with distilled water (seeds: water, 1:5) and submitted to steam distillation about 4hr. via Clevenger- type apparatus. The collected oils were dried by passing over anhydrous sodium sulfate on a filter paper( Whatman No.1) in a glass funnel. The oils were stored in a sealed glass bottle at $4^{\circ} \mathrm{C}$ until subsequent tests (AOAC, 2005).

\section{Determination of physicochemical properties of essential oils :}

- Specific gravity determined by using a pycnometer (10ml capacity).

- Rferactive index determined by using zeiss refractometer at $20{ }^{\circ} \mathrm{C}$.

- Optical rotation determined using polarimeter.

- Acid number, ester number and iodine number were determined according to method of AOAC (2005).

\section{Preparation of pizza:}

Pizza was prepared according the method described by Larsen et al. (1993). The following ingredients were used for manufacturing pizza dough samples: $1000 \mathrm{~g}$ flour, $25 \mathrm{~g}$ yeast, $5 \mathrm{~g}$ sugar, $1 \mathrm{gm}$ salt, $200 \mathrm{ml}$ corn oil, $50 \mathrm{~g}$ egg and sufficient water to make cohesive dough constant consistency. The quantities of water, sugar and yeast were put in a cup to be mixed well and after waiting about $5 \mathrm{~min}$. for the activation of yeast the mixture was transferred to a large mixing bowel. The flour quantities were added followed by salt and oil to be mixed with fork to let all the liquid absorbed by the flour. The dough was Kneaded for 8-10 min. on pastry board until the texture was smooth and uniform. The dough was placed in a bowel and drizzle with corn oil covered with a cloth, let to rise for about an hour. The dough was punch down and after about $45 \mathrm{~min}$. The topping of each pizza consists of $30 \mathrm{gm}$ paste 
tomato, $25 \mathrm{gm}$ green pepper, $30 \mathrm{gm}$ black olive and $30 \mathrm{gm}$ turkey cheese. pizza dough was put in the oven at $170^{\circ} \mathrm{C}$ for 30 min. The pizza samples were packed in polypropylene film and stored at $5^{\circ} \mathrm{C}$ in refrigerator.

\section{Sensory evaluation of pizza:}

The characteristics of pizza included, color, taste, odor, texture and general appearance were sensory evaluated according to method of Larsen et al. (1993).

\section{Essential oils analysis by Gas chromatography-Mass spectrometry (GC-MS):}

The analysis of the essential oils was performed using a Hewlett Packard (Waldbronn, Germany) $5890 \mathrm{II}$ GC, equipped with a $30 \mathrm{~m} \times 0.25 \mathrm{~mm}$ i.d., $0.25 \mu \mathrm{m} \mathrm{HP}$ 5 MS capillary column and HP 5972 mass selective detector. For GC-MS detection an electron ionization system was used with ionization energy of $70 \mathrm{eV}$. Helium was the carrier gas, at a flow rate of $1 \mathrm{~mL} / \mathrm{min}$. Injector and MS transfer line temperatures were set at $220^{\circ} \mathrm{C}$ and $290^{\circ}$, respectively. Column temperature was initially at $50^{\circ} \mathrm{C}$, then gradually increased to $150^{\circ} \mathrm{C}$ at a $3^{\circ} \mathrm{C} / \mathrm{min}$ rate, held for $10 \mathrm{~min}$ and finally increased to $250^{\circ} \mathrm{C}$ at $10^{\circ} \mathrm{C} / \mathrm{min}$. Diluted samples (1/100 in acetone) of $1.0 \mu \mathrm{L}$ were injected manually and splitless. Identification of the components was based on the comparison of their mass spectra with those of NBS75 K library data of the GC-MS system and literature data. The results were also confirmed by the comparison of the compounds elution order with their relative retention indices on non-polar phases reported in the literature (Adams, 2001).

\section{Antimicrobial disk assay:}

Antibacterial and antifungai (molds and yeast) activities of three $\mathrm{EO}_{s}$ were investigated by the disk diffusion method (Xhu et al., 2004). The MHA plates, containing an in column size of $10^{6} \mathrm{CFU} / \mathrm{ml}$ of bacteria or $2 \times 10^{5} \mathrm{CFU} / \mathrm{ml}$ yeast cells or molds spores on SDA and PDA plates, respectively, were spread on the solid plates with an L-shaped glass rod. Then, disks (6.0 $\mathrm{mm}$ in diameter) impregnated with each extract at a different concentration and placed on the inoculated plates. All of the plates were incubated at $37^{\circ} \mathrm{C}$ for $24 \mathrm{~h}$. for bacteria and at $28^{\circ} \mathrm{C}$ for $48 \mathrm{~h}$. for fungi. The sensitivity of the microorganisms species to the $\mathrm{EO}_{\mathrm{s}}$ was determined by measuring the sizes of the inhibitory zones (including the diameter of disk) on the agar surface around the disks. All of the experiments were performed in duplicate. The results are reported as the average of two experiments.

\section{Total count of microorganisms in pizza:}

Total Microbial count and fungi (mold \& yeast) count were determined according to methods of AOAC (2005). 


\section{Statistical analysis:}

The obtained data were statistically analyzed using Statistical Analysis System SAS (2001).

\section{RESULTS AND DISCUSSION}

\section{Physicochemical properties of essential oils:}

The physicochemical properties of essential oils extracted from dill, celery and parsley seeds were determined and the obtained results were tabulated as shown in Table (1). The values of specific gravity, refractive index, optical rotation, acid number, ester number and iodine number are within the ranges reported by Food Chemical Codex (1981). Meanwhile, Badei et al. (2008) declared that the quality of any essential oil and consequently its value and applications are highly correlated with its chemical constituents which directly affect the physicochemical characteristics of these essential oils.

\section{Sensory evaluation of pizza:}

With regard to sensory evaluation of pizza after directly baking the data in Table (2) summarized mean values of color, taste, odor, texture and general appearance. It could be deduced from results that addition of dill, celery and parsley seeds at levels 1.5 and $2 \%$ and its essential oils at levels 400 and 600 ppm did not significantly affect on values of sensory evaluation of pizza compared with control pizza with the exception of both color pizza when dill, celery and parsley seeds were added and taste of pizza when essential oil of dill seeds was added whereas significantly different compared with control. In the meantime Anitescu et al. (1997) indicated that essential oils have a complex composition, containing several hundred constituents, especially hydrocarbons (terpenes and sesquiterpenes) and oxygenated compounds (alcohols, aldehydes, ketones, acids, phenols, oxides, lactones, acetyls, ethers and esters). Both hydrocarbons and oxygenated compounds are responsible for the characteristic odor and flavors.

\section{Chemical components of essential oils:}

Table (3) and figures (1), (2) \& (3) illustrated the Gas chromatography-Mass spectrometry (GC/MS) profiles of essential oils. The results appeared that myristicin, camphene and $\beta$-Pinene were the major components present in dill seeds essential oil. Meanwhile, limonene, camphene and $\beta$-Pinene were the major components present in celery seeds essential oil. At the same time, $\beta$-Phellandrene, myristicin and limonene were the major components present in parsley seeds essential oil. On the contrary, nerodiol and elemicin were not detected in celery seeds essential oil, while, P-cymene 
was not detected in parsley seeds essential oil under the condition of the experiment in essential oil.

\section{Antimicrobial activities of essential oils:}

Concerning the antimicrobial effect of extracted essential oils the results in Table (4) demonstrated that the essential oils were greater antimicrobial activity in gram positive bacteria than that in gram negative bacteria. These results are in agreement with those obtained by Sue and Young (2000), who observed that gram positive bacteria were more susceptible to inhibition by plant essential oil than gram negative bacteria. This finding could be elucidated by Sue and Young (2000) who reported that gram negative bacteria have a cell wall covered by an outer membrane, phospholipids and some protein, this structure may be prevent either the uptake of the oils or protect the peptidoglycan layer from the oils. The outer lipopolysaccharide (LPS) membrane of gram negative bacteria presents a permeability barrier to hydrophobic substances that can enter and inhibit the growth of gram positive bacteria. In gram positive bacteria, the peptidoglycan layer is on the outside and more available to contact with the oils. Some of the antimicrobial compounds in certain oils may fall into this category, explaining the increased resistance of gram negative bacteria to particular oils since these oil components could not enter the cell as easily.

Regarding antimolds effect of essential oils, the data in Table (4) indicated that three essential oils were higher antimolds activity than that of bacteria and yeast. This result coincide with that mentioned by Shelef (1980) who found that molds are more sensitive than bacteria.

Respecting antiyeast effect of essential oils, the results in Table (4) showed that three essential oils exhibited weak activity against yeast.

Branen et al. (1980) mentioned that the mechanism of microorganisms decreasing might be related to the destruction or inactivation of essential enzyme and/or genetic material. Also, inhibition DNA, RNA and protein synthesis. They also added that the monoglycerides depressed the NADH oxidase system by acting on the $\mathrm{O}_{2}$ side of flavine of NADH dehydrogenase. Maria et al. (1996) found that celery and dill essential oils showed antibacterial, antilisteria and antifungal activity. The same author indicated that there is a relationship between the chemical composition of the essential oil and its antimicrobial effect.

\section{Total count of microorganisms in pizza:}

With respect to total bacterial count and fungi (molds \& yeast) count (CFU/gm) in pizza samples, the results in Table (5) revealed that the antimicroorganisms activity of dill, celery and parsley seeds and its essential oils extracted from these seeds could be ranked as follows dill > parsley > celery. From 
the same table it could be observed that three essential oils were higher or greater antimicroorganisms than powder seeds specially $600 \mathrm{ppm}$ from essential oils. Therewithal, the pizza samples were found to be free of the microorganisms at zero time. In addition to, pizza samples containing different levels of seeds and its essential oils had a longer shelf life compared with control sample (without additives). This effect is due to that seeds and essential oils contains numerous compounds that have inhibitory properties against the growth of microorganisms. Wei and Wang (2001) mentioned that total phenolic content in dill and parsley seeds were 3.12 and 1.12 $\mathrm{mg} / \mathrm{g}$ as gallic acid equivalents respectively (on fresh weight basis), while Vinson et al. (1998) found that total phenolic content in celery seeds was $1.2 \mu \mathrm{mol} / \mathrm{g}$ as catchin equivalents (on fresh weight basis), and they evinced that microorganisms in foods are influenced by the intrinsic characteristics of foods (i.e., $\mathrm{pH}$, moisture level, oxidation-reduction potential, nutrient content, antimicrobial constituents, biological structures, chemical composition of the food and shape or size of the food) and extrinsic characteristics (i.e., temperature, humidity and gases of the environment. Also, the physical and chemical composition of the microorganisms and their stage of existence (vegetative cell, spore, and phase of growth, moist or wet, etc.)

In conclusion, the aforementioned results declared that physicochemical properties of essential oils were in standard limit. Sensory evaluation of pizza showed that pizza color with three seeds additives and pizza taste with dill seeds essential oil added significantly differed taste compared with control sample. GC/MS apparatus estimated 15, 13 and 14 components present in dill, celery and parsley essential oils respectively. Antimicrobial activity of essential oils indicated that essential oils gave greater antimicrobial activity in gram positive bacteria than that in gram negative bacteria, Also, essential oils had higher antimolds activity than that of bacteria and yeast. Total count of microorganisms in pizza revealed that adding three essential oils increased shelf life of pizza as compared with adding the three seeds. Generally, three seeds and its essential oils have broad inhibitory activities to microorganisms and are promising for incorporation into various food products and an ideal candidate for uses for food preservation. 
Table 1. Physicochemical properties of essential oils $\left(E_{s}\right)$

\begin{tabular}{|l|l|l|l|}
\hline \multicolumn{1}{|c|}{ Characteristics } & \multicolumn{1}{c|}{ Dill seeds EO } & \multicolumn{1}{c|}{ Celery seeds EO } & \multicolumn{1}{c|}{ Parsley seeds EO } \\
\hline Specific gravity $\left(\right.$ at $15^{\circ} \mathrm{C}$ ) & 0.901 & 0.891 & 1.050 \\
\hline Refractive index $\left(\right.$ at $20^{\circ} \mathrm{C}$ ) & 1.4835 & 1.4782 & 1.4910 \\
\hline Optical rotation & $+94^{\circ} 0^{\prime}$ & $+55^{\circ} 0^{\prime}$ & $-60{ }^{\circ} 0^{\prime}$ \\
\hline Acid number & 1.03 & 1.50 & 1.48 \\
\hline Ester number & 35.31 & 18.0 & 9.75 \\
\hline Iodine number & 112.3 & 94.8 & 109.5 \\
\hline
\end{tabular}

Table 2. Sensory evaluation of pizza after directly baking* .

\begin{tabular}{|c|c|c|c|c|c|}
\hline Treatments & $\begin{array}{l}\text { Color } \\
(10)\end{array}$ & $\begin{array}{l}\text { Taste } \\
(10)\end{array}$ & $\begin{array}{l}\text { Odor } \\
(10)\end{array}$ & $\begin{array}{c}\text { Texture } \\
(10)\end{array}$ & $\begin{array}{c}\text { General } \\
\text { appearance (10) }\end{array}$ \\
\hline Pizza (control) & $\begin{array}{r}8.95 \\
\pm 0.26 \mathrm{a} \\
\end{array}$ & $\begin{array}{r}9.52 \\
\pm 0.30 \mathrm{a} \\
\end{array}$ & $\begin{array}{r}9.10 \\
\pm 0.27 a \\
\end{array}$ & $\begin{array}{r}9.00 \\
\pm 0.08 \mathrm{a} \\
\end{array}$ & $\begin{array}{r}9.14 \\
\pm 0.15 \mathrm{a} \\
\end{array}$ \\
\hline Pizza $+1.5 \%$ dill seeds & $\begin{array}{r}7.81 \\
\pm 0.24 \mathrm{~b} \\
\end{array}$ & $\begin{array}{r}8.85 \\
\pm 0.34 a \\
\end{array}$ & $\begin{array}{r}9.13 \\
\pm 0.15 \mathrm{a} \\
\end{array}$ & $\begin{array}{r}9.10 \\
\pm 0.22 \mathrm{a} \\
\end{array}$ & $\begin{array}{r}8.93 \\
\pm 0.19 a \\
\end{array}$ \\
\hline Pizza $+2 \%$ dill seeds & $\begin{array}{r}7.12 \\
\pm 0.19 \mathrm{~b} \\
\end{array}$ & $\begin{array}{r}8.79 \\
\pm 0.39 a \\
\end{array}$ & $\begin{array}{r}9.17 \\
\pm 0.30 \mathrm{a} \\
\end{array}$ & $\begin{array}{r}9.16 \\
\pm 0.21 \mathrm{a} \\
\end{array}$ & $\begin{array}{r}8.89 \\
\pm 0.33 a \\
\end{array}$ \\
\hline Pizza $+1.5 \%$ celery seeds & $\begin{array}{r}7.18 \\
\pm 0.25 \mathrm{~b} \\
\end{array}$ & $\begin{array}{r}8.90 \\
\pm 0.28 \mathrm{a} \\
\end{array}$ & $\begin{array}{r}9.11 \\
\pm 0.25 \mathrm{a} \\
\end{array}$ & $\begin{array}{r}9.11 \\
\pm 0.40 \mathrm{a} \\
\end{array}$ & $\begin{array}{r}8.49 \\
\pm 0.18 \mathrm{a} \\
\end{array}$ \\
\hline Pizza $+2 \%$ celery seeds & $\begin{array}{r}7.12 \\
\pm 0.33 \mathrm{~b} \\
\end{array}$ & $\begin{array}{r}8.83 \\
\pm 0.21 \mathrm{a} \\
\end{array}$ & $\begin{array}{r}9.14 \\
\pm 0.19 a \\
\end{array}$ & $\begin{array}{r}9.13 \\
\pm 0.37 \mathrm{a} \\
\end{array}$ & $\begin{array}{c}8.41 \\
\pm 0.22 \mathrm{a} \\
\end{array}$ \\
\hline Pizza $+1.5 \%$ parsley seeds & $\begin{array}{r}7.70 \\
\pm 0.29 \mathrm{~b} \\
\end{array}$ & $\begin{array}{r}8.72 \\
\pm 0.12 \mathrm{a} \\
\end{array}$ & $\begin{array}{r}9.18 \\
\pm 0.24 a \\
\end{array}$ & $\begin{array}{r}9.00 \\
\pm 0.25 \mathrm{a} \\
\end{array}$ & $\begin{array}{r}8.37 \\
\pm 0.31 \mathrm{a} \\
\end{array}$ \\
\hline Pizza $+2 \%$ parsley seeds & $\begin{array}{r}7.31 \\
\pm 0.09 \mathrm{~b} \\
\end{array}$ & $\begin{array}{r}8.60 \\
\pm 0.34 a \\
\end{array}$ & $\begin{array}{r}9.21 \\
\pm 0.31 \mathrm{a} \\
\end{array}$ & $\begin{array}{r}9.10 \\
\pm 0.20 \mathrm{a} \\
\end{array}$ & $\begin{array}{c}8.37 \\
\pm 0.10 \mathrm{a} \\
\end{array}$ \\
\hline Pizza +400 ppm EO dill seeds & $\begin{array}{r}8.35 \\
\pm 0.20 \mathrm{a} \\
\end{array}$ & $\begin{array}{r}8.25 \\
\pm 0.29 \mathrm{~b} \\
\end{array}$ & $\begin{array}{r}8.55 \\
\pm 0.18 \mathrm{a} \\
\end{array}$ & $\begin{array}{r}9.14 \\
\pm 0.10 \mathrm{a} \\
\end{array}$ & $\begin{array}{r}9.57 \\
\pm 0.17 a \\
\end{array}$ \\
\hline $\begin{array}{l}\text { Pizza +600 ppm dill seeds } \\
\text { essential oil }\end{array}$ & $\begin{array}{r}8.19 \\
\pm 0.40 \mathrm{a} \\
\end{array}$ & $\begin{array}{r}8.11 \\
\pm 0.15 \mathrm{~b} \\
\end{array}$ & $\begin{array}{r}8.50 \\
\pm 0.15 \mathrm{a} \\
\end{array}$ & $\begin{array}{r}9.17 \\
\pm 0.19 \mathrm{a} \\
\end{array}$ & $\begin{array}{r}9.61 \\
\pm 0.09 \mathrm{a} \\
\end{array}$ \\
\hline $\begin{array}{l}\text { Pizza }+400 \text { ppm celery seeds } \\
\text { essential oil }\end{array}$ & $\begin{array}{r}8.17 \\
\pm 0.16 a \\
\end{array}$ & $\begin{array}{r}8.96 \\
\pm 0.17 a \\
\end{array}$ & $\begin{array}{r}8.90 \\
\pm 0.20 \mathrm{a} \\
\end{array}$ & $\begin{array}{r}9.22 \\
\pm 0.26 \mathrm{a} \\
\end{array}$ & $\begin{array}{r}9.30 \\
\pm 0.25 \mathrm{a} \\
\end{array}$ \\
\hline $\begin{array}{l}\text { Pizza }+600 \text { ppm celery seeds } \\
\text { essential oil }\end{array}$ & $\begin{array}{r}8.12 \\
\pm 0.35 \mathrm{a} \\
\end{array}$ & $\begin{array}{r}8.21 \\
\pm 0.27 a \\
\end{array}$ & $\begin{array}{r}8.75 \\
\pm 0.28 \mathrm{a} \\
\end{array}$ & $\begin{array}{r}9.00 \\
\pm 0.38 \mathrm{a} \\
\end{array}$ & $\begin{array}{r}9.37 \\
\pm 0.35 \mathrm{a} \\
\end{array}$ \\
\hline $\begin{array}{l}\text { Pizza }+400 \text { ppm parsley seeds } \\
\text { essential oil }\end{array}$ & $\begin{array}{r}8.15 \\
\pm 0.39 a \\
\end{array}$ & $\begin{array}{r}8.70 \\
\pm 0.16 \mathrm{a} \\
\end{array}$ & $\begin{array}{r}9.00 \\
\pm 0.32 \mathrm{a} \\
\end{array}$ & $\begin{array}{r}9.20 \\
\pm 0.11 \mathrm{a} \\
\end{array}$ & $\begin{array}{r}8.76 \\
\pm 0.30 \mathrm{a} \\
\end{array}$ \\
\hline $\begin{array}{l}\text { Pizza }+600 \text { ppm parsley seeds } \\
\text { essential oil }\end{array}$ & $\begin{array}{r}8.90 \\
\pm 0.15 \mathrm{a} \\
\end{array}$ & $\begin{array}{r}8.67 \\
\pm 0.35 \mathrm{a} \\
\end{array}$ & $\begin{array}{r}8.89 \\
\pm 0.18 \mathrm{a} \\
\end{array}$ & $\begin{array}{r}9.00 \\
\pm 0.36 \mathrm{a} \\
\end{array}$ & $\begin{array}{r}8.80 \\
\pm 0.17 \mathrm{a} \\
\end{array}$ \\
\hline L.S.D. $(0.05)$ & 0.20 & 0.16 & N.S & N.S & N.S \\
\hline
\end{tabular}

$*$ Values are mean \pm standard error.

* Values in the same column with different superscript letters $(a, b, \ldots)$ are significantly different. 
Table 3. Chemical components of essential oils fraction by GC/MS technique.

\begin{tabular}{|l|c|c|c|}
\hline \multirow{2}{*}{ Components } & \multicolumn{3}{|c|}{ Percentage (\%) } \\
\cline { 2 - 4 } & Dill seeds EO & Celery seeds EO & Parsley seeds EO \\
\hline$\alpha$-Pinene & 9.69 & 6.07 & 5.84 \\
\hline Camphene & 17.71 & 15.31 & 3.98 \\
\hline$\beta$-Pinene & 13.94 & 7.28 & 4.95 \\
\hline$\beta$-Phellandrene & 8.06 & 2.00 & 25.77 \\
\hline Limonene & 10.68 & 26.43 & 14.27 \\
\hline Myristicin & 28.27 & 2.54 & 18.85 \\
\hline Camphor & 11.59 & 3.63 & 7.05 \\
\hline Linalool & 7.55 & 4.38 & 10.72 \\
\hline P-Cymene & 0.85 & 1.29 & - \\
\hline$\alpha$-Terpinene & 2.13 & 1.50 & 1.21 \\
\hline Eugenol & 5.46 & 2.33 & 1.30 \\
\hline Carvone & 2.80 & 2.40 & 1.75 \\
\hline Nerodiol & 0.91 & - & 0.65 \\
\hline Apiole & 2.18 & 2.19 & 1.24 \\
\hline Elemicin & 0.79 & - & 0.51 \\
\hline
\end{tabular}

Table 4. Effect of essential oils (EOs) on growth inhibition zone diameter ( $\mathrm{mm}$ ) of microorganisms.

\begin{tabular}{|c|c|c|c|c|c|c|c|}
\hline & & \multicolumn{2}{|c|}{ Dill seeds EO } & \multicolumn{2}{|c|}{ Celery seeds EO } & \multicolumn{2}{|c|}{ Parsley seeds EO } \\
\hline & & $\begin{array}{l}400 \\
\text { ppm }\end{array}$ & 600 & $\begin{array}{l}400 \\
\mathrm{ppm}\end{array}$ & $\begin{array}{l}600 \\
\mathrm{ppm}\end{array}$ & 400 & $\begin{array}{l}600 \\
\mathrm{ppm}\end{array}$ \\
\hline \multirow{4}{*}{$\begin{array}{l}\text { I } \\
\frac{E}{0} \\
\frac{0}{0}\end{array}$} & Bacillus cereus & 11 & 17 & 10 & 11 & 10 & 13 \\
\hline & Bacillus subtilis & 14 & 21 & 8 & 10 & 9 & 14 \\
\hline & Listeria monocytogenes & 16 & 19 & 11 & 12 & 12 & 16 \\
\hline & Staphylococcus Aureus & 15 & 24 & 11 & 14 & 12 & 17 \\
\hline \multirow{2}{*}{ 焉 I } & Escherichia coli & 9 & 12 & 8 & 12 & 8 & 10 \\
\hline & $\begin{array}{l}\text { Pseudomonas } \\
\text { aeruginosa }\end{array}$ & 8 & 15 & 9 & 11 & 8 & 12 \\
\hline \multirow{4}{*}{$\frac{\text { 믕 }}{\sum}$} & Aspergillus niger & 19 & 26 & 12 & 14 & 15 & 18 \\
\hline & Fuzarium oxysporum & 20 & 25 & 13 & 14 & 13 & 18 \\
\hline & Penicillium citrnium & 18 & 25 & 11 & 15 & 13 & 15 \\
\hline & Rhizopus nigricans & 20 & 27 & 12 & 13 & 14 & 17 \\
\hline Yeast & Candida albicans & 3 & 5 & 1 & 2 & 2 & 5 \\
\hline
\end{tabular}




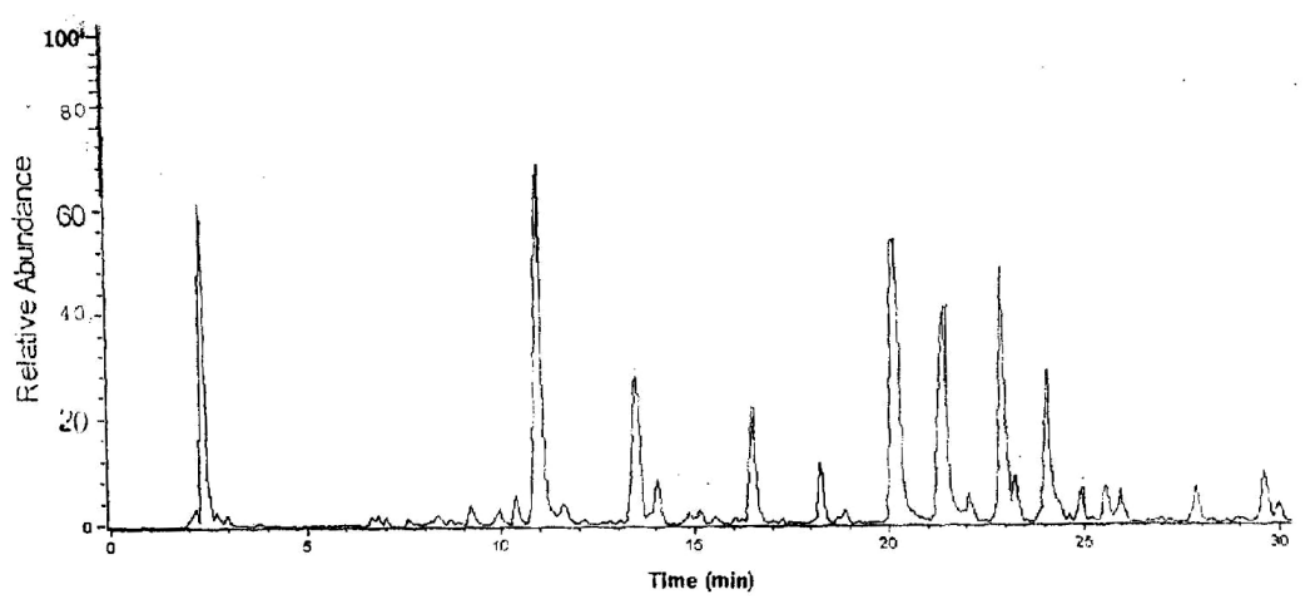

Figure 1. GCMS chromatogram of dill seeds essential oil components.

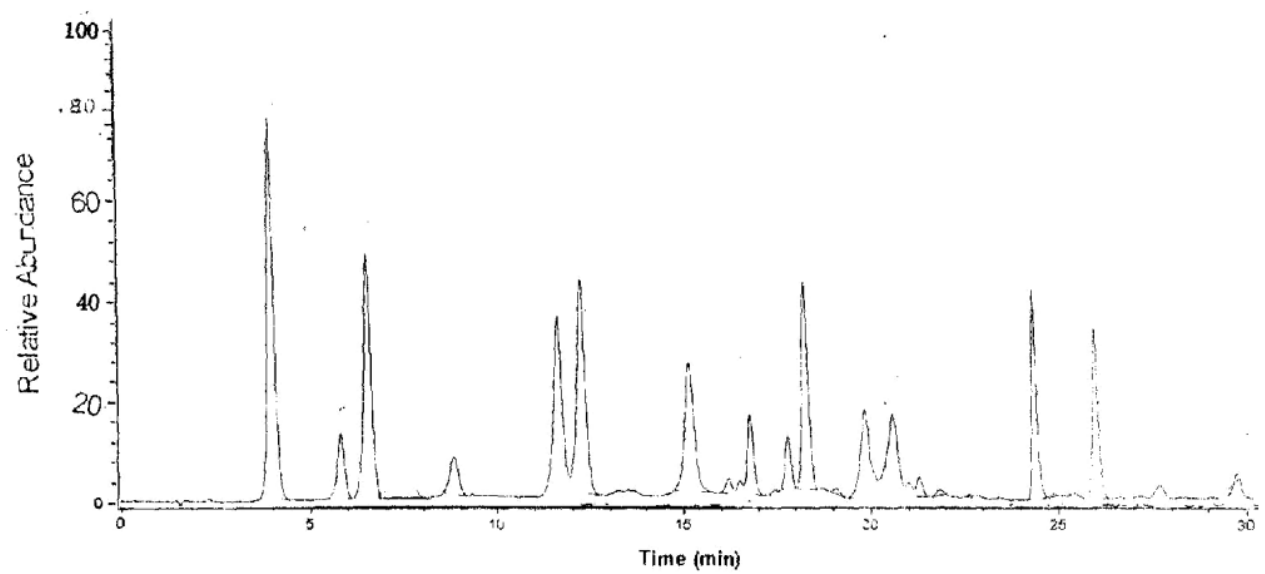

Figure 2. GCMS chromatogram of celery seeds essential oil components.

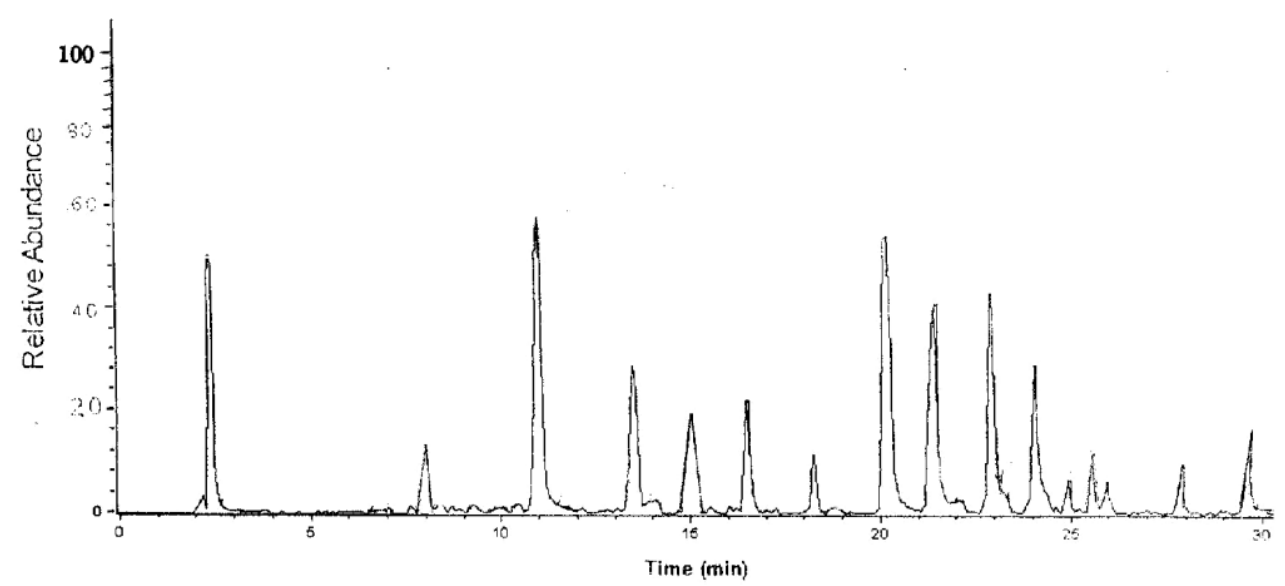

Figure 3. GCMS chromatogram of parsley seeds essential oil components. 
Table 5. Effect of seeds and essential oils on total count of microorganisms in pizza (CFU/gm).

\begin{tabular}{|c|c|c|c|c|c|c|c|c|}
\hline \multirow{3}{*}{ Treatments } & \multicolumn{8}{|c|}{ Storage period (days) } \\
\hline & \multicolumn{2}{|c|}{ Zero time } & \multicolumn{2}{|c|}{5 days } & \multicolumn{2}{|c|}{10 days } & \multicolumn{2}{|c|}{15 days } \\
\hline & Bacteria & Fungi & Bacteria & Fungi & Bacteria & Fungi & Bacteria & Fungi \\
\hline Control & ND & ND & $3.1 \times 10^{2}$ & $\begin{array}{l}1.8 \times \\
10^{2}\end{array}$ & Ex 7 & days & & \\
\hline \multicolumn{9}{|l|}{ Seeds: } \\
\hline Dill $1.5 \%$ & ND & ND & $1.0 \times 10^{2}$ & ND & $2.3 \times 10^{2}$ & $1.0 \times 10$ & \multicolumn{2}{|l|}{ Ex 12 days } \\
\hline Dill $2 \%$ & ND & ND & $8.0 \times 10$ & ND & $1.7 \times 10^{2}$ & ND & \multicolumn{2}{|l|}{ Ex 13 days } \\
\hline Celery $1.5 \%$ & ND & ND & $2.5 \times 10^{2}$ & $\begin{array}{l}1.0 \times \\
10^{2} \\
\end{array}$ & \multicolumn{2}{|l|}{ Ex 9 days } & & \\
\hline Celery $2 \%$ & ND & ND & $2.0 \times 10^{2}$ & ND & $2.7 \times 10^{2}$ & $1.9 \times 10^{2}$ & \multicolumn{2}{|l|}{ Ex 11 days } \\
\hline Parsley $1.5 \%$ & ND & ND & $2.3 \times 10^{2}$ & $\begin{array}{l}8.0 \times \\
10 \\
\end{array}$ & \multicolumn{2}{|c|}{ Ex 10 days } & & \\
\hline Parsley 2\% & ND & ND & $1.4 \times 10^{2}$ & ND & $2.1 \times 10^{2}$ & $\begin{array}{l}1.0 \times \\
10^{2}\end{array}$ & \multicolumn{2}{|l|}{ Ex 12 days } \\
\hline \multicolumn{9}{|l|}{ Oils: } \\
\hline Dill 400 ppm & ND & ND & $3 \times 10$ & ND & $1.1 \times 10^{2}$ & $1.0 \times 10$ & \multicolumn{2}{|l|}{ Ex 13 days } \\
\hline Dill 600 ppm & ND & ND & $1 \times 10$ & ND & $7.0 \times 10$ & ND & \multicolumn{2}{|l|}{ Ex 15 days } \\
\hline $\begin{array}{l}\text { Celery } 400 \\
\text { ppm }\end{array}$ & ND & ND & $7 \times 10$ & ND & $2.1 \times 10^{2}$ & $\begin{array}{l}2.0 \times \\
10^{2}\end{array}$ & \multicolumn{2}{|l|}{ Ex 11 days } \\
\hline $\begin{array}{l}\text { Celery } 600 \\
\text { ppm }\end{array}$ & ND & ND & $3 \times 10$ & ND & $9.0 \times 10$ & $2 \times 10$ & \multicolumn{2}{|l|}{ Ex 11 days } \\
\hline $\begin{array}{l}\text { Parsley } 400 \\
\text { ppm }\end{array}$ & ND & ND & $5 \times 10$ & ND & $1.9 \times 10^{2}$ & $9.0 \times 10$ & \multicolumn{2}{|l|}{ Ex 11 days } \\
\hline $\begin{array}{l}\text { Parsley } 600 \\
\text { ppm }\end{array}$ & ND & ND & $2 \times 10$ & ND & $1.6 \times 10^{2}$ & ND & \multicolumn{2}{|l|}{ Ex 13 days } \\
\hline
\end{tabular}

Fungi are molds and yeast.

ND means not detected.

Ex means expired date.

\section{REFERENCES}

1. Adams, R.P. 2001. Identification of essential oils components by gas chromatography / quadrupole mass spectroscopy. Allured Publishing Corporation: Illinois, II.

2. Anitescu, G., C. Doneanu and V. Radulescu. 1997. Isolation of coriander oil: comparison between steam distillation and supercritical $\mathrm{CO}_{2}$ extraction. Flavour and fragrance Journal, 12: 173-176.

3. AOAC 2005. Official Methods of Analysis, $18^{\text {th }}$ Ed. Association Official Analytical Chemists, Arlington, Virginia, USA.

4. Badei, A. Z., M.A. Mohamed and M.I. Mohamed. 2008. Physicochemical, chemical composition and safety of carrot herb, mandarin peel, Clementine peel and petitgrain mandarin volatile oils. The $3^{\text {rd }}$ International Conference on Food Science and Nutrition, Cairo, Egypt. 
5. Branen, A.L., P.M. Davidson and B. Katz. 1980. Antimicrobial properties of phenolic antioxidants and lipids. Food Technology, 34 (5): 42-53.

6. Farrell. K.T. 1999. Spices, Condiments and Seasoning $2^{\text {nd }}$ Ed., PP 60, 89, 162. The AVI publishing Co., Inc. Westport Connecticut.

7. Food Chemicals Codex. 1981. "Food Chemicals Codex", $3^{\text {rd }}$ Ed. National Academy Press, Washington. D.C.

8. Karapinar, M., T. Gündüz and S. Gönül. 2005. The potential use of spices and extracts as the disinfectant agents fresh produce 2nd International Conference "Future Trends in Food Science and Nutrition", National Research Center, Cairo, Egypt.

9. Larsen, D.M., C.S. Setser and J.M. Faubion. 1993. Effect of flour type and dough retardation time on the sensory characteristics of pizza crust; Cereal Chem. 70 (6) $647-650$.

10. Maria, L., S. Hart, S. Deans and E. Eaglesham. 1996. Comparison of the pharmacological and antimicrobial action of commercial plant essential oils. Journal of Herbs, Spices \& Medicinal Plants, 4 (2): 64-86.

11. Miean, K.H. and S. Mohamed. 2001. Flavonoid (Myricetin, Quercetin, Kaempferol, Luteol in and apigenin) Content of Edible Tropical Plants. J. Agric. Food Chem., 49: 3106-3112.

12. Sacchetti,G., J.S. Maietti, M. Muzzoli, M. Scaglianti and S. Manfredini. 2005. Comparative evaluation of different essential oils of different origin as functional antioxidants, antiradicals and antimicrobials in foods. Food Chemistry, 91. 621 632

13. SAS 2001. Statistical Analysis System. SAS User's Guide: Statistics (Version 6.0) SAS Inc. Cary. North Carolina, USA.

14. Shelef, L.A., O.A. Naglik and d.w. Bogen. 1980. Sensitivity of some common food borne bacteria to the spices sage, rosemary and allspice. J. Food Sci., 45: 10421044.

15. Sue, C. and D.G. Young. 2000. Screening for inhibitory activity of essential oils on selected bacterial, fungi and viruses. J. Essent. Oil Res., 12: 639-649.

16. Vinson, J.A., Y. Hao; X. Su and L. Zubik. 1998. Phenol antioxidant quantity and quality in foods: vegetables. J. Agric. Food chem., 46: 3630-3634.

17. Wei, Z. and S. Wang. 2001. Antioxidant activity and phenolic compounds in selected herbs. J. Agric. Food Chem., 49: 5165-5170.

18. Zhu, X.; H. Zhang and R. Lo. 2004. Phenolic compouns from the leaf extract of artichoke (Cynara scolymus L.) and their antimicrobial activities. J. Agric. Food Chem., 52: 7272-7279. 
استخدام إضافات طبيعية لزيادة فترة صلاحية البيتزا

أيمن عزت محمد سليمان، هالة محمد زكى على، نادية محمود عبدالمطلب

$$
\text { معرُ بحوث تكنولوجيا الأغذية - مركز البحوث الزراعية - الجيزة - مصر }
$$

فى السنوات الأخيرة يوجد اهتمام زائد لاستخدام المركبات الطبيعية كمضادات للميكروبات بسبب

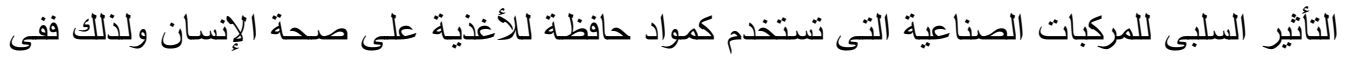

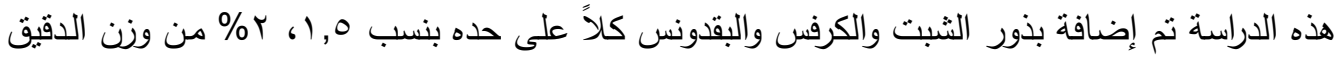

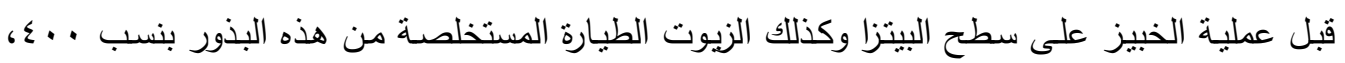

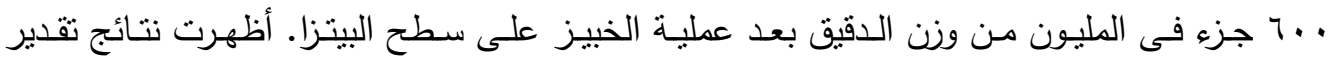

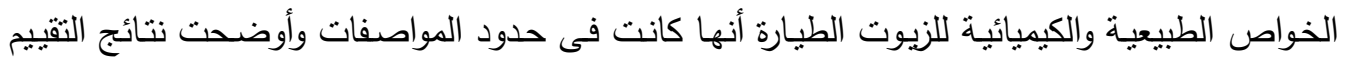

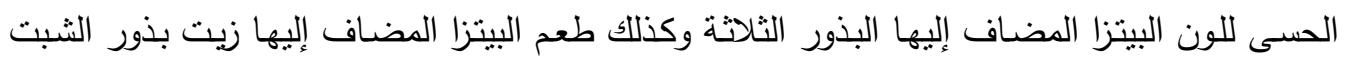
اختلفت معنويًا بالمقارنـة بعينة الكنترول. كما تم التعرف على مكونات الزيوت الطيارة باستخدام جهاز

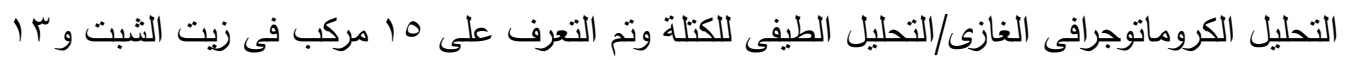

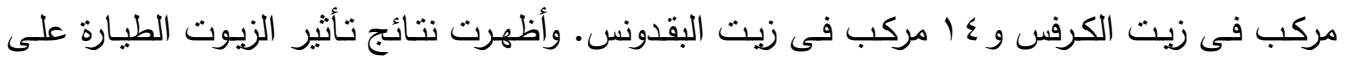

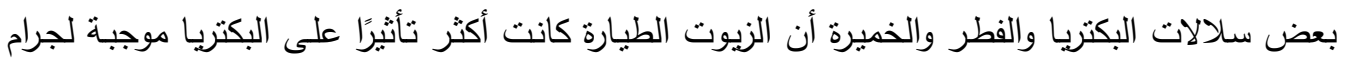

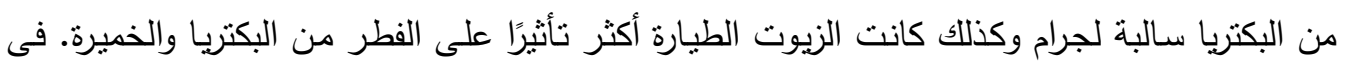

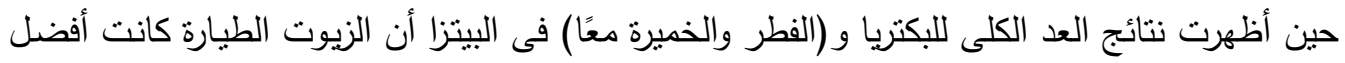
من البذور فى إطالة فترة صلاحية البيتزا. 